\title{
Contents, Volume 3 (1992)
}

Bilewicz-Pawińska, T.: see Varis, A.-L. \& BilewiczPawińska, T.

117

Clayhills, T.: Coleoptera finds from the coastal area of the Bothnian Bay 98

Clayhills, T.: On the identity of Quedius limbatus (Heer) and $Q$. limbatoides Coiff. (Coleoptera, Staphylinidae) and their distribution in Fennoscandian countries ........ 14

Ferrer, J.: see Mannerkoski, I. \& Ferrer, J. ................... 95

Halme, J.: Ephedrus (Ephedrus) koponeni sp. n. from Finland (Hymenoptera, Braconidae, Aphidiinae) ...... 113

Heikinheimo, O.: Aphidoidea of Åland, SW Finland ... 57

Heliövaara, K., Väisänen, R., Varama, M. \& Viitasaari, M.: Gynandromorphic individuals of Neodiprion sertifer (Hymenoptera, Diprionidae) 149

Jansson, A.: Parasigara multilineata de Sallier Dupin, 1973, a synonym of Corixa monticola Linnavuori, 1971, and notes on distribution of African species of Corixa (Heteroptera, Corixidae) 171

Jansson, A.: The identity of the Spinola Collection Corixidae (Heteroptera) 173

Jussila, R.: Ichneumonidae (Hymenoptera) new to Finland. II. 159

Kaila, L. \& Kerppola, S.: Elachista leifi sp. n. from northern Finland (Lepidoptera, Elachistidae) ............... 155

Kaila, L. \& Kerppola, S.: Records of Microlepidoptera from Finland 1990 (Lepidoptera)

Kaila, L.: The Elachistidae of southern Siberia and Central Asia, with descriptions of five new species (Lepidoptera).

177

Karppinen, E., Melamud, V. V., Miko, L. \& Krivolutsky, D. A.: Further information on the oribatid fauna (Acarina, Oribatei) of the northern palearctic region: Ukraina and Czechoslovakia

Kerppola, S.: see Kaila, L. \& Kerppola, S. 41

S.

Kerppola, S.: see Kaila, L. \& Kerppola, S. ................. 155

Koponen, S. \& Marusik, Yu. M.: Spiders (Araneae) from Central Yakutia, Siberia 163

Krivolutsky, D. A.: see Karppinen, E., Melamud, V. V., Miko, L. \& Krivolutsky, D. A. ............................... 41

Lammes, T.: Eurygaster maurus (L.) excluded from the fauna of Finland (Heteroptera, Scutelleridae) ...... 111

Linnavuori, R. E.: Hemiptera of Iraq. I. Heteroptera, Miridae (Deraeocorinae, Dicyphinae, Mirinae, and Orthotylinae)

223

Linnavuori, R. E.: The lateralis group of the genus Dimorphocoris Reuter of Greece and the Middle East (Heteroptera, Miridae, Halticini) .....
Mannerkoski, I. \& Ferrer, J.: Cynaeus opacus Champion, a new tenebrionid beetle in Finland (Coleoptera, Tenebrionidae) ...................................................... 95

Marusik, Yu. M.: see Koponen, S. \& Marusik, Yu. M. .. 163 Melamud, V. V.: see Karppinen, E., Melamud, V. V., Miko, L. \& Krivolutsky, D. A. .............................. 41

Miko, L.: see Karppinen, E., Melamud, V. V., Miko, L. \& Krivolutsky, D. A. ................................................ 41

Nartshuk, E. P.: Revision of the species of Meromyza Meigen (Diptera, Chloropidae) from Finland ...... 121

Nilsson, A. N.: A revision of the East African Nebrioporus abyssinicus group (Coleoptera, Dytiscidae) ........... 81

Nupponen, K. \& Nupponen, T.: Noctua janthina and $N$. janthe (Lepidoptera, Noctuidae) in Finland ............. 9

Nupponen, T.: See Nupponen, K. \& Nupponen, T. ........ 9

Pajunen, I.: see Pajunen, V. I. \& Pajunen, I. ................. 15

Pajunen, V. I. \& Pajunen, I.: Field evidence of intra- and interspecific predation in rock-pool corixids (Heteroptera, Corixidae) 15

Silfverberg, H.: Amara gebleri Dejean in Finland (Coleoptera, Carabidae) 167

Storozhenko, S.: Permian fossil insects of North-East Europe: new and little-known Ideliidae (Insecta, Plecopteroidea, Grylloblattida) 21

Šulcs, I.: Elachista nolckeni sp. n. aus Lettland (Lepidoptera, Elachistidae) 105

Šulcs, I.: Neue und wenig bekannte Arten der LepidopterenFauna Lettlands. 13. Mitteilung ............................. 99

Tobias, V. I.: see Yakovlev, E. B. \& Tobias, V. I. ..... 139

Tomminen, J.: The effect of beetles on the dispersal stages of Bursaphelenchus mucronatus Mamiya \& Enda (Nematoda: Aphelenchoididae) in wood chips of Pinus sylvestris $\mathrm{L}$. ...

195

Väisänen, R.: see Heliövaara, K., Väisänen, R., Varama, M. \& Viitasaari, M. ............................................. 149

Varama, M.: see Heliövaara, K., Väisänen, R., Varama, M. \& Viitasaari, M. 149

Varis, A.-L. \& Bilewicz-Pawińska, T.: Influence of temperature on survival and emergence of diapausing Peristenus stenodemae (Hymenoptera, Braconidae) ..

117

Viitasaari, M.: see Heliövaara, K., Väisänen, R., Varama, M. \& Viitasaari, M.

Weslien, J.: The arthropod complex associated with Ips typographus (L.) (Coleoptera, Scolytidae): species composition, phenology, and impact on bark beetle productivity 
Yakovlev, E. B. \& Tobias, V. I.: Braconidae (Hymenoptera) parasites of fungivorous Diptera in Karelia . 139

\section{Short reports}

Albrecht, A.: Baizongia pistaciae (Linnaeus) (Homoptera, Pemphigidae) new to Finland .

Albrecht, A.: Geoica setulosa (Passerini) (Homoptera, Pemphigidae) new to Finland ................................... 5

Albrecht, A.: Protrama flavescens (Koch) (Homoptera, Lachnidae) new to Finland .

Albrecht, A.: Smynthurodes betae Westwood (Homoptera, Pemphigidae) new to Finland

Biström, O. \& Rutanen, I.: Attagenus smirnovi Zhantiev (Coleoptera, Dermestidae) - today an established indoor pest in Eastern Fennoscandia?

Clayhills, T.: Cryptophagus obsoletus Reitter (Coleoptera, Cryptophagidae) new to Finland ............................. 2

Clayhills, T.: Lionychus quadrillum (Duftschmid) (Coleoptera, Carabidae), second record from Finland, and Sibinia primita (Herbst) (Coleoptera, Curculionidae) found in Parainen, SW Finland

Deletions from the fauna of Finland

Faunistic rarities ............................................................... 7

Helve, E.: Longitarsus ochroleucus (Marsham) (Coleoptera, Chrysomelidae) new to Finland ............................... 4

Helve, E.: Thamiaraea hospita (Märkel) (Coleoptera, Staphylinidae) new to Finland ..................................... 4

Kaila, L.: Demetrias imperialis (Germar) (Coleoptera, Carabidae) new to Finland ...................................... 3

Kangas, E.: Altica carduorum (Guérin-Ménéville) and Altica quercetorum saliceti Weise (Coleoptera, Chrysomelidae) new to Finland

Kangas, E.: Further records of Anthonomus brunnipennis Curtis (Coleoptera, Curculionidae) from Finland and Karelia

New provincial records

Päivinen, J.: Amphipyra livida (Lepidoptera, Noctuidae) new to Finland .....

Rinne, V.: Piesma salsolae (Becker) (Heteroptera, Piesmatidae) new to Finland
Rosengren, R.: Tapinoma melanocephalum (Fabricius) (Hymenoptera, Formicidae) a new housepest in Finland 6

Rutanen, I. \& Rassi, P.: Second record of Galerucella grisescens (Joannis) (Coleoptera, Chrysomelidae) from Finland

Rutanen, I.: Rare or interesting beetles (Coleoptera) from Leivonmäki (Sa) and Savonranta (Sb), central Finland 4

Silfverberg, H.: Anthonomus brunnipennis Curtis (Coleoptera, Curculionidae) new to Finland ....................... 1

Silfverberg, H.: Brachycercus harrisella Curtis (Ephemeroptera, Caenidae) in Finland ................................ 4

Silfverberg, H.: Crioceris asparagi (L.) (Coleoptera, Chrysomelidae) found in Finland .... 2

\section{Literature reviews}

Bailey, W. J. \& Rentz, D. C. F. (eds.): The Tettigoniidae Biology, Systematics and Evolution. (U. Carlberg) .... 214

Block, W.: An annotated bibliography of Antarctic invertebrates (terrestrial and freshwater). (L. Huldén) . 176

Coulianos, C.-C. \& Holmåsen, I.: Galler. En fälthandbok om gallbildningar på vilda och odlade växter. (L. Huldén) ............................................................... 204

Emmet, A. M. \& Heath, J. (eds.): The Moths and Butterflies of Great Britain and Ireland. (L. Huldén \& L. Kaila) 40

Emmet, A. M.: The Scientific Names of the British Lepidoptera - their History and Meaning. (K. Mikkola) .. 109

Gerling, D. (ed.): Whiteflies: their Bionomics, Pest Status and Management. (L. Huldén) 169

Kosztarab, M. \& Kozar, F.: Scale Insects of Central Europe. (L. Huldén) ...................................................... 20

Salmon, J. T.: The Stick Insects of New Zealand. (U. Carlberg) 80

Watt, A. D., Leather, S. R., Hunter, M. D. \& Kidd, N. A. C. (eds.): Population Dynamics of Forest Insects. (O. Biström) 154 